\title{
Salt-Enrichment Impact on Biomass Production in a Natural Population of Peatland Dwelling Arcellinida and Euglyphida (Testate Amoebae)
}

\author{
Alex Whittle ${ }^{1,2}$ (D) Matthew J. Amesbury ${ }^{1,3} \cdot$ Dan J. Charman ${ }^{1} \cdot$ Dominic A. Hodgson ${ }^{2,4} \cdot$ Bianca B. Perren $^{2}$. \\ Stephen J. Roberts ${ }^{2} \cdot$ Angela V. Gallego-Sala $^{1}$
}

Received: 6 August 2018 / Accepted: 15 November 2018 / Published online: 11 December 2018

(C) The Author(s) 2018

\begin{abstract}
Unicellular free-living microbial eukaryotes of the order Arcellinida (Tubulinea; Amoebozoa) and Euglyphida (Cercozoa; SAR), commonly termed testate amoebae, colonise almost every freshwater ecosystem on Earth. Patterns in the distribution and productivity of these organisms are strongly linked to abiotic conditions - particularly moisture availability and temperaturehowever, the ecological impacts of changes in salinity remain poorly documented. Here, we examine how variable salt concentrations affect a natural community of Arcellinida and Euglyphida on a freshwater sub-Antarctic peatland. We principally report that deposition of wind-blown oceanic salt-spray aerosols onto the peatland surface corresponds to a strong reduction in biomass and to an alteration in the taxonomic composition of communities in favour of generalist taxa. Our results suggest novel applications of this response as a sensitive tool to monitor salinisation of coastal soils and to detect salinity changes within peatland palaeoclimate archives. Specifically, we suggest that these relationships could be used to reconstruct millennial scale variability in salt-spray deposition - a proxy for changes in wind-conditions-from sub-fossil communities of Arcellinida and Euglyphida preserved in exposed coastal peatlands.
\end{abstract}

Keywords Testate amoebae $\cdot$ Sub-Antarctica $\cdot$ Salinity $\cdot$ Southern hemisphere westerly winds $\cdot$ Bioindicators

Arcellinida and Euglyphida (AE) belong to a polyphyletic group of test-forming protozoans that are widely used in environmental biomonitoring and palaeoclimatology $[1,2]$. Despite the predominant association of most taxa with freshwater ecosystems (e.g. lakes, soils, peatlands) the distribution of active communities also extends into many moderately

Electronic supplementary material The online version of this article (https://doi.org/10.1007/s00248-018-1296-8) contains supplementary material, which is available to authorized users.

Alex Whittle

aw424@exeter.ac.uk

1 Department of Geography, University of Exeter, Exeter EX4 4RJ, UK

2 British Antarctic Survey, Natural Environment Research Council, High Cross, Madingley Road, Cambridge CB3 0ET, UK

3 Environmental Change Research Unit (ECRU), Faculty of Biological and Environmental Sciences, University of Helsinki,

Helsinki, Finland

4 Department of Geography, Durham University, Durham DH1 3LE, UK saline environments [3-8]. Nevertheless, like other microbial groups $[9,10]$, physiological and metabolic challenges exerted by differing salinity conditions appear to be reflected in the global and local distribution of AE. Only a small percentage of taxa are known to occur in marine ecosystems [e.g. 11], and salinity conditions have been linked to patterns in the distribution of taxa within lakes contaminated by road salt run-off $[12,13]$, anchialine pools [14], and saltmarshes [3, $15,16]$. However, the importance of salinity in defining the distribution of taxa, community structure, and size of AE populations remains uncertain.

We directly examined changes in a population of AE along an uninterrupted salinity gradient from brackish to freshwater conditions within a west-facing coastal peatland on subAntarctic Marion Island (Fig. 1). Correlation between saltenrichment and coastal exposure is a characteristic feature of ecosystems on the sub-Antarctic islands which results from intense generation and deposition of oceanic salt-spray by strong prevailing westerly winds [17]. Soil-dwelling AE communities were described from 28 samples exposed to varying levels of relative salt-enrichment which was quantified by measuring the conductivity of pore-water, a direct proxy for 


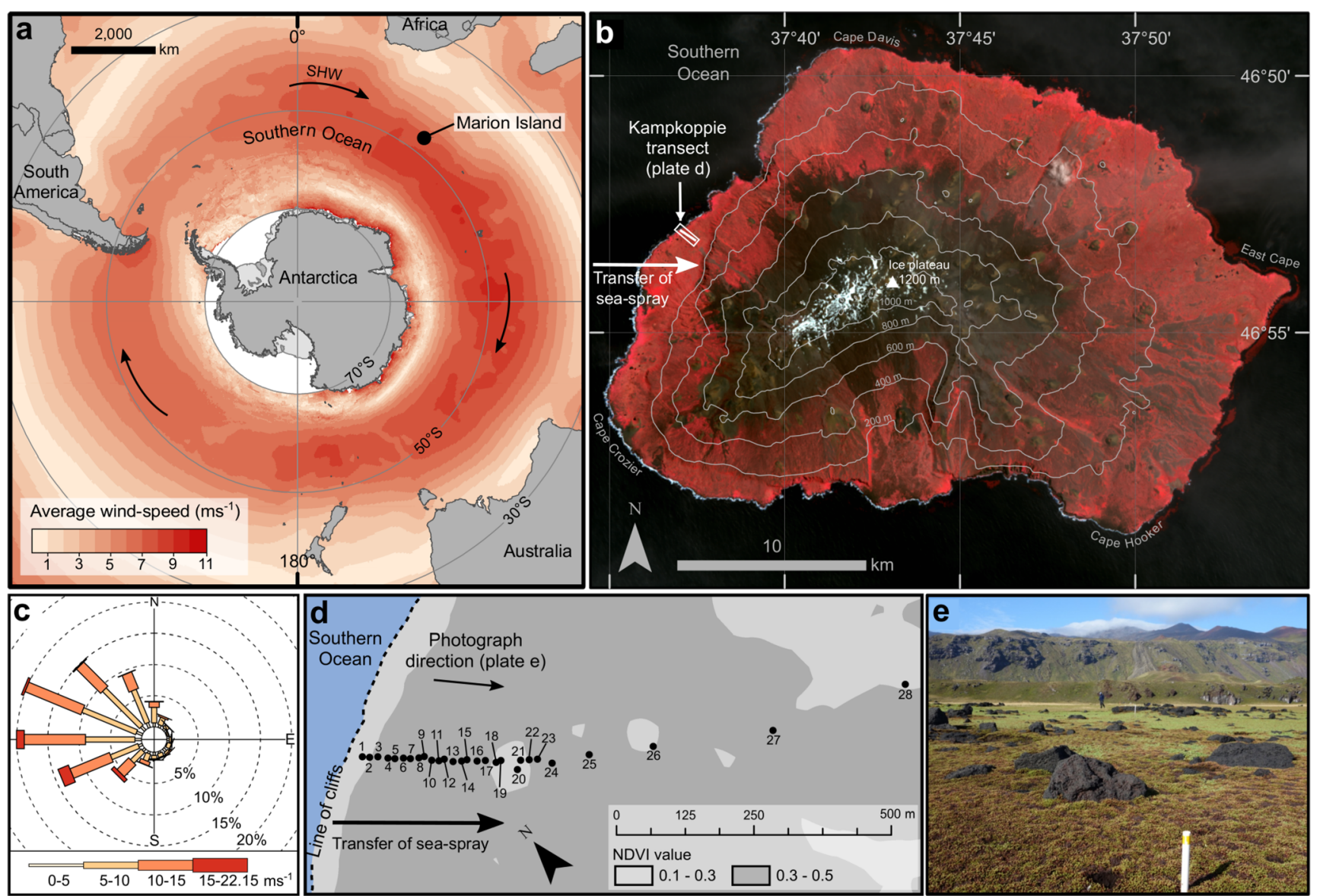

Fig. 1 a Location of Marion Island in the Southern Indian Ocean province of sub-Antarctica and within the core belt of the Southern Hemisphere Westerly winds (SHW). Arrows indicate prevailing atmospheric circulation. Annual sea surface-level $(10 \mathrm{~m})$ mean wind speeds are based on NOAA blended high resolution ( 0.25 degree grid) vector data downloaded from (https://www.ncdc.noaa.gov/data-access/ marineocean-data/blended-global/blended-sea-winds), and are calculated from monthly mean values for the period 1995-2005. b False-colour satellite image indicating vegetation cover (red shading) and the peatland at Kampkoppie where samples were collected. Image courtesy of the US Geological Survey (http://earthexplorer.usgs.gov/). c Wind-rose derived from daily NOAA blended sea-winds data (source as Fig. 1a) for the period 2008-2018, indicating the prevailing winds from

microhabitat salinity (Fig. 1; Supplementary methods). Principal component (PC) analysis confirmed that conductivity was the primary ecological gradient represented by the samples (Fig. 2a) and suggested that atmospheric deposition of oceanic salt-spray was the dominant cause of elevated salinity (see Supplementary methods). The peatland transect, which spanned a coastal terrace $\sim 30 \mathrm{~m}$ above sea-level, represented a model system for assessing the ecological importance of salinity because; (1) the carbon and moisture rich substrate provides consistent conditions for colonisation, (2) confounding micro-environmental conditions thought to affect the distribution of $\mathrm{AE}$ in other salt-influenced systems were controlled, and (3) the low-energy depositional the west-north-west. Wind strengths and frequency were calculated for wind directions at 22.5 degree intervals. $\mathbf{d}$ Locations of samples (marked 1-28) within the gradient of salt-enrichment at Kampkoppie. Normalised difference vegetation index (NDVI) values indicate minor changes in the vegetation cover at the peatland surface. e Photograph of the peatland surface looking east from the coast and showing the lack of topographic variability along the sampled gradient. Vegetation is characteristic of exposed coastal areas with a salt-spray complex of Cotula plumosa and Crassula moschata (foreground) and exhibits a distinct succession with distance inland. Palaeocliffs visible in the background mark the most inland extent of the sampling transect (Photograph source: Dominic Hodgson)

environment limits potential for contamination of assemblages by allochthonous tests.

We recorded a diverse fauna of 34 taxa from 21 genera, including 17 taxa not previously identified on Marion Island (Supplementary figure S1; table S1). We also report the first known occurrence of Quadrulella symmetrica within the sub-, maritime-, or continental Antarctic region. Taxa belonging to the third major group of testate amoebae, Amphitrematidae (Labyrinthulids; SAR), were not present in these samples.

Marked differences in the $\mathrm{AE}$ fauna were observed between samples. Canonical correspondence analysis (CCA) indicated that measured conductivity is (or is linearly related to) the main determinant of assemblages (i.e. relative taxon 


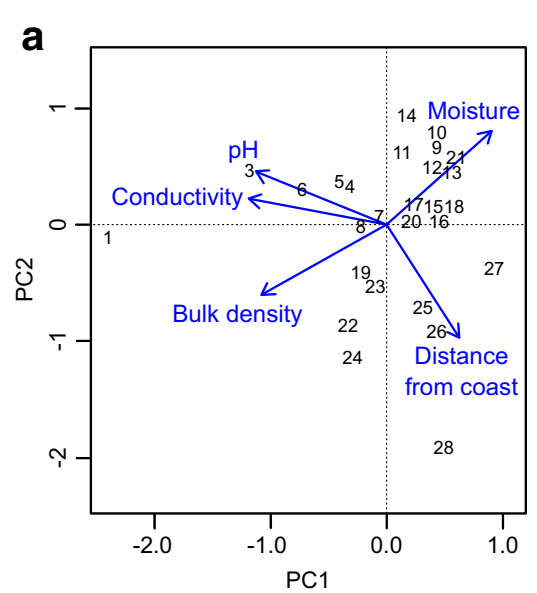

Fig. 2 a Principal component (PC) analysis of environmental conditions represented in the sampled communities of Arcellinida and Euglyphida. Numbers indicate sample locations within the salinity gradient labelled sequentially with distance inland from the coastline (see Fig. 1d). High correlation between conductivity and $\mathrm{pH}$ of pore-water $\left(R^{2}=0.82\right.$, $p<0.001)$ and distance inland from the coast is indicative of oceanic salt-spray inputs, which cause a simultaneous increase in ionic strength and $\mathrm{pH}$ of the otherwise freshwater and acidic peatland ecosystem (i.e., both $\mathrm{pH}$ and conductivity act as proxies for salt-enrichment in this environment). b Canonical correspondence analysis (CCA) tri-plot representing the relationship between key micro-environmental variables

abundance) in the sampled communities denoting a connection between AE fauna and magnitude of salt-enrichment (Fig. $2 b)$. In total, conductivity accounted for $\sim 48 \%$ of explained variance in the assemblages, and also explained the largest independent portion of variance after removing the contributions of confounding microhabitat variables (Supplementary table S4). Despite major differences in habitat, this relationship corroborates the role of salinity as a driver of assemblage changes suggested from observations of freshwater lakes exposed to salt addition of a comparable magnitude $[12,13]$.

Although the distribution of samples is skewed toward lower salinity conditions, tight clustering at the centre of CCA axis 1 indicates that saline conditions are sub-optimal for the majority of taxa. Accordingly, communities exposed to high concentrations of salt-spray deposition generally presented lower taxonomic-richness and evenness, implying that many taxa are selectively excluded by high salinity conditions (Fig. 3). Opportunistic generalist taxa from the genus Centropyxis [16] which have been suggested to exhibit moderately euryhaline ecology $[13,14]$ are a notable exception. These taxa dominated high salinity communities and possibly benefit from reduced competition caused by exclusion of other taxa (Supplementary figure S2).

To test whether salinity elicits quantifiable changes beyond the distribution of individual taxa, we examined variability in total biomass ([18, 19]; Supplementary methods). Biomass co-varied with alpha-diversity and denotes a major distinction between productive freshwater communities and depauperate,

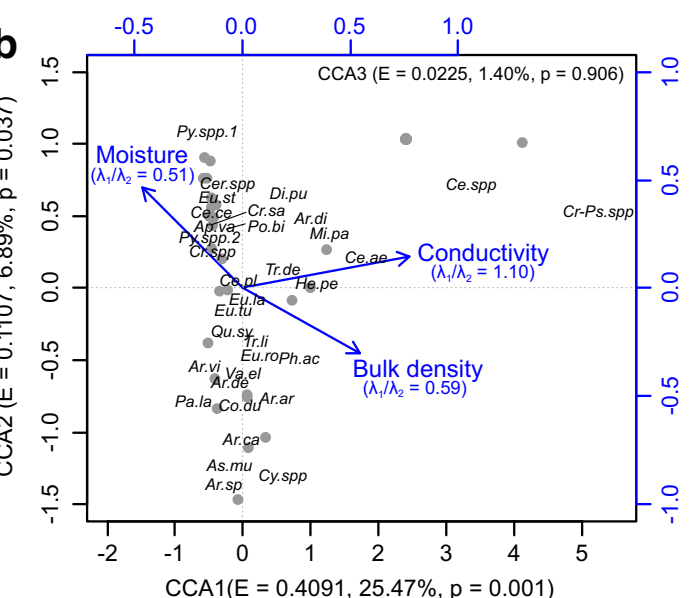

and taxonomic assemblages. The ratio $>1$ between the first constrained $\left(\lambda_{1}\right)$ and unconstrained axis $\left(\lambda_{2}\right)$ from a partial CCA run individually for each micro-environmental variable shows that conductivity is the main determinant of relative taxon abundance. $\mathrm{pH}$ and distance from the coast were removed from analysis due to their high correlation with conductivity. Eigenvalues (E) and percentage of variance in assemblage data explained by each axis is shown. Values of each environmental variable increase in the direction of the arrow. Abbreviations of individual taxa are given in supplementary table S1. Grey markers designate the distribution of samples. Full summaries of analysis are given in supplementary table $\mathrm{S} 2$ and $\mathrm{S} 3$

less productive salt-enriched communities (Fig. 3). Specifically, biomass and conductivity are linked by a highly significant, negative logarithmic relationship $\left(R^{2}=0.6394\right.$, $p=<0.001)$. Arcellinida and Euglyphida responded consistently $\left(R^{2}=0.6283 / 0.6234\right.$ respectively, both $\left.p=<0.001\right)$; although, as a more diverse taxonomic group, Arcellinida contributed a larger portion to total biomass. This relationship held when communities in samples exhibiting high conductivity values - i.e. $>2$ millisiemens per centimetre $(\mathrm{mS} / \mathrm{cm})$ were sequentially excluded (Supplementary figure S3). Our data therefore indicates that $\mathrm{AE}$ are highly sensitive even to small perturbations in salinity; for the least saline sample included in this study, an increase in microhabitat conductivity of only $0.25 \mathrm{mS} / \mathrm{cm}$ (from 0.58 to $0.83 \mathrm{mS} / \mathrm{cm}$ ) was estimated to result in a $50 \%$ biomass reduction.

$\mathrm{AE}$ are important heterotrophs in peatlands $[18,20,21]$ and consume a wide range of microbial prey (i.e. bacteria, other protozoa, fungi, algae [22]). Following this, it is possible that the observed variability in $\mathrm{AE}$ biomass reflects unmeasured differences in the availability of these prey microorganisms. To test this, we examined correlations between conductivity conditions and the prevalence of functional-traits linked to feeding ecology. However, no significant relationships were found to support this interpretation (Supplementary table S5). Additionally, we did not observe the presence of foraminifera which can coexist with $\mathrm{AE}$ in brackish environments $[8,14$, 16] and may compete for resources. Abiotic factors, therefore, appear to be more influential than feeding interactions in 


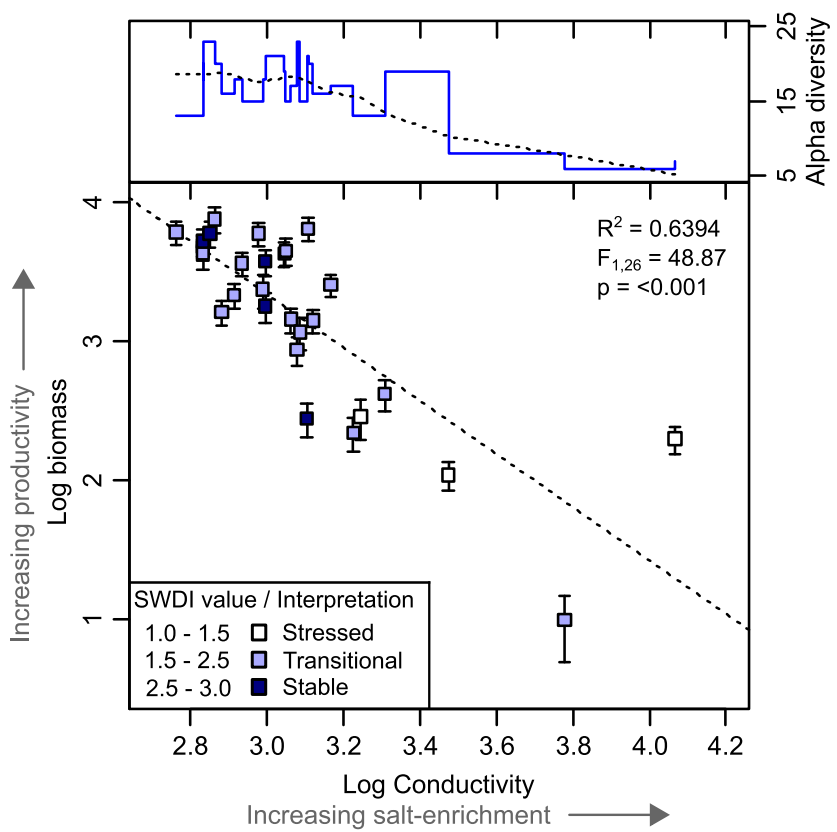

Fig. 3 Relationship between pore-water conductivity and AE alpha-diversity, Shannon-Weaver diversity index (SWDI) and community biomass. Conductivity of pore-water was used as an indicator of saltenrichment level in each community. Higher diversity, SWDI value and biomass are indicative of more productive AE communities. Interpretation of SWDI values indicate the favourability of environmental conditions for AE colonisation; healthy faunas in stable environments are characterised by high values, whereas low values represent faunas dominated by a small number of taxa under stressed environmental conditions $[16,27]$. Conductivity (microsiemens/cm) and biomass ( $\mathrm{g} \mathrm{C} \mathrm{g} \mathrm{dry-soil}^{-1}$ ) were $\log _{10}(\mathrm{x})$ transformed. Error bars represent uncertainty in community biomass calculated using upper and lower estimates of $\mathrm{AE}$ concentration and standardised values for taxon-specific biovolume (Supplementary methods)

governing the distribution and abundance of AE under these conditions, although more research is needed into potential variability in predation pressure.

The relationship between AE biomass and salinity was largely independent from patterns in species turnover. Variability in biomass was driven primarily by the abundance of individuals (population size) despite large differences in the sizes of the individual assemblage constituents (Supplementary table S6). Accordingly, population size was strongly correlated with conductivity $\left(R^{2}=0.6631, p<0.001\right)$, which is consistent with observations linking reduced concentrations of $\mathrm{AE}$ to greater marine influence in coastal marshes [e.g. 6, 23].

AE taxa perform reproduction either (1) via asexual binary fission, (2) as a result of sexual life-cycles, or (3) as a combination of both strategies [24]. Test dimensions are set either during or shortly after reproduction and so it is assumed that cells maintain a fixed biovolume throughout their lifetime [but see 25]. Therefore, if both a constant rate of predation pressure and constant decay rate of empty tests is assumed, observed biomass is related directly to the rate of reproduction.
Consequently, we suggest that reduced biomass is partly the result of an increased energetic cost associated with osmoregulation which is progressively traded-off against reproduction under increasing salinity. Most taxa appear not to be adapted to conditions where pore-water conductivity exceeds $3.0 \mathrm{mS} / \mathrm{cm}$ which may mark the transition to a prevailing hypertonic environment (Fig. 3). This explanation linking the ionic strength of the AE microhabitat with communitylevel biomass is also consistent with a reduction in biomass observed after artificial nutrient addition to an Arctic fendwelling community [19].

The highly sensitive response of AE biomass, combined with patterns in the diversity and distribution of taxa, offer substantive potential for the use of these organisms as a bioindicator of environmental salinity. Application of these relationships to sub-fossil AE communities could considerably advance palaeoclimatology by providing, for the first time, millennial scale records of changes in atmospheric circulation recorded by salt-spray aerosol deposition onto coastal peatlands. Additionally, AE could play an important role in monitoring salinisation of coastal peatland ecosystems that are vulnerable to increased inundation under projected sea-level rise [see 26]. Biomass especially appears to offer a highly sensitive proxy for relative salt-enrichment, with the benefit of increased analytical efficiency over traditional approaches which require identification of individual taxa. More research should be conducted to confirm that comparable responses are observed under both experimental laboratory conditions and in other salt-stressed soil ecosystems.

Our results indicate for the first time that the effects of saltenrichment on AE communities extend beyond previously documented changes in taxonomic composition to include strong effects on biomass production. AE offer potential as bioindicators of salinity with the capability to resolve low magnitude changes in salt-enrichment, such as deposition of wind-blown oceanic salt-spray.

Acknowledgements We thank Prof. Steven L. Chown for sponsoring our visits to Marion Island with the South African National Antarctic Program. Dominic Hodgson carried out fieldwork with support from Dr. Bernard Coetzee, Mashudu Mashau, and Rashawi Kgopong of the University of Stellenbosh, RSA. Dr. Elie Verleyen and Dr. Wim Van Nieuwenhuyze of the University of Ghent, Belgium, carried out initial site reconnaissance. Members of the Marion Island wintering teams M69 and M70, and Starlight Aviation provided local support and access to the field sites. Alex Whittle was supported by a Natural Environment Research Council GW4+ DTP studentship, grant number NE/L002434/ 1. We are thankful for the constructive suggestions made by Edward Mitchell and two anonymous reviewers.

\section{Compliance with Ethical Standards}

Conflict of Interest The authors declare that they have no conflict of interest. 
Open Access This article is distributed under the terms of the Creative Commons Attribution 4.0 International License (http:// creativecommons.org/licenses/by/4.0/), which permits unrestricted use, distribution, and reproduction in any medium, provided you give appropriate credit to the original author(s) and the source, provide a link to the Creative Commons license, and indicate if changes were made.

\section{References}

1. Charman DJ (2001) Biostratigraphic and palaeoenvironmental applications of testate amoebae. Quat Sci Rev 20:1753-1764

2. Kosakyan A, Gomaa F, Lara E, Lahr DJ (2016) Current and future perspectives on the systematics, taxonomy and nomenclature of testate amoebae. Eur J Protistol 55:105-117

3. Charman DJ, Roe HM, Gehrels WR (1998) The use of testate amoebae in studies of sea-level change: a case study from the Taf Estuary, South Wales, UK. The Holocene 8:209-218

4. Golemansky V (1998) Interstitial testate amoebae (Rhizopoda: Testacea) from the Italian coast of the Mediterranean Sea. Acta Protozool 37:139-143

5. Heger TJ, Mitchell EAD, Todorov M, Golemansky V, Lara E, Leander BS, Pawlowski J (2010) Molecular phylogeny of euglyphid testate amoebae (Cercozoa: Euglyphida) suggests transitions between marine supralittoral and freshwater/terrestrial environments are infrequent. Mol Phylogenet Evol 55:113-122

6. Ooms M, Beyens L, Temmerman S (2012) Testate amoebae as proxy for water level changes in a brackish tidal marsh. Acta Protozool 51:271-289

7. Camacho S, Connor S, Asioli A, Boski T, Scott D (2015) Testate amoebae and tintinnids as spatial and seasonal indicators in the intertidal margins of Guadiana estuary (southeastern Portugal). Ecol Indic 58:426-444

8. Barnett RL, Newton TL, Charman DJ, Gehrels WR (2017) Saltmarsh testate amoebae as precise and widespread indicators of sealevel change. Earth Sci Rev 164:193-207

9. Lozupone CA, Knight R (2007) Global patterns in bacterial diversity. Proc Natl Acad Sci 104:11436-11440

10. Logares R, Bråte J, Bertilsson S, Clasen JL, Shalchian-Tabrizi K, Rengefors K (2009) Infrequent marine-freshwater transitions in the microbial world. Trends Microbiol 17:414-422

11. Nicholls KH (2009) Six new marine species of the genus Paulinella (Rhizopoda: Filosea, or Rhizaria: Cercozoa). J Mar Biol Assoc U K 89:1415-1425

12. Roe HM, Patterson RT, Swindles GT (2010) Controls on the contemporary distribution of lake thecamoebians (testate amoebae) within the Greater Toronto Area and their potential as water quality indicators. J Paleolimnol 43:955-975

13. Roe HM, Patterson RT (2014) Arcellacea (testate amoebae) as bioindicators of road salt contamination in lakes. Microb Ecol 68:299313
14. Van Hengstum PJ, Reinhardt EG, Beddows PA, Huang RJ, Gabriel JJ (2008) Thecamoebians (testate amoebae) and foraminifera from three anchialine cenotes in Mexico: low salinity (1.5-4.5 psu) faunal transitions. J Foraminifer Res 38:305-317

15. Charman DJ, Roe HM, Gehrels WR (2002) Modern distribution of saltmarsh testate amoebae: regional variability of zonation and response to environmental variables. J Quat Sci 17:387-409

16. Riveiros NV, Babalola AO, Boudreau REA, Patterson RT, Roe HM, Doherty C (2007) Modern distribution of salt marsh foraminifera and thecamoebians in the Seymour-Belize Inlet Complex, British Columbia, Canada. Mar Geol 242:39-63

17. Saunders KM, Hodgson DA, McMurtrie S, Grosjean M (2015) A diatom-conductivity transfer function for reconstructing past changes in the southern hemisphere westerly winds over the Southern Ocean. J Quat Sci 30:464-477

18. Royles J, Amesbury MJ, Roland TP, Jones GD, Convey P, Griffiths H, Hodgson DA, Charman DJ (2016) Moss stable isotopes (carbon13 , oxygen-18) and testate amoebae reflect environmental inputs and microclimate along a latitudinal gradient on the Antarctic Peninsula. Oecologia 181:931-945

19. Mitchell EAD (2004) Response of testate amoebae (Protozoa) to N and P fertilization in an Arctic wet sedge tundra. Arct Antarct Alp Res 36:78-83

20. Jassey VEJ, Chiapusio G, Binet P, Buttler A, Laggoun-Défarge F, Delarue F, Bernard N, Mitchell EAD, Toussaint M-L, Francez A-J, Gilbert D (2013) Above- and belowground linkages in Sphagnum peatland: climate warming affects plant-microbial interactions. Glob Chang Biol 19:811-823

21. Gilbert D, Amblard C, Bourdier G, Francez A-J (1998) The microbial loop at the surface of a peatland: structure, function, and impact of nutrient input. Microb Ecol 35:83-93

22. Gilbert D, Amblard C, Bourdier G, Francez A-J, Mitchell EAD (2000) Le régime alimentaire des thécamoebiens (Protista, Sarcodina). Année Biol 39:57-68

23. Barnett RL, Charman DJ, Gehrels WR, Saher MH, Marshall WA (2013) Testate amoebae as sea-level indicators in Northwestern Norway: developments in sample preparation and analysis. Acta Protozool 52:115-128

24. Lahr DJG, Parfrey LW, Mitchell EAD, Katz LA, Lara E (2011) The chastity of amoebae: re-evaluating evidence for sex in amoeboid organisms. Proc R Soc B Biol Sci 278:2081-2090

25. Pchelin IM (2011) Testate amoeba Arcella vulgaris (Amoebozoa, Arcellidae) is able to survive without the shell and construct a new one. Protistology 6:251-257

26. Whittle A, Gallego-Sala AV (2016) Vulnerability of the peatland carbon sink to sea-level rise. Sci Rep 6:28758

27. Patterson RT, Kumar A (2002) A review of current testate rhizopod (thecamoebian) research in Canada. Palaeogeogr Palaeoclimatol Palaeoecol 180:225-251 